\title{
Krzysztof Bokwa*
}

ORCID: 0000-0002-7625-6809

Uniwersytet Jagielloński

https://doi.org/10.19195/1733-5779.33.10

\section{Larva, calumnia, homagium. Delikty i szkoda niemajątkowa w dziewiętnastowiecznym prawie węgierskim}

\section{JEL Classification: K15}

Słowa kluczowe: homagium, prawo węgierskie, prawo zobowiązań, odpowiedzialność deliktowa, historia prawa

Keywords: homagium, Hungarian law, obligation law, tortious liability, legal history

\begin{abstract}
Abstrakt: Celem artykułu jest opis i analiza regulacji naprawienia szkody niemajątkowej w dawnym prawie węgierskim ze szczególnym uwzględnieniem instytucji homagium. Autor przedstawia zarys dziejów prawa węgierskiego w XIX wieku i jego specyfikę objawiającą się w długotrwałej ciągłości i zarazem archaiczności. Następnie analizuje systematykę deliktów w ówczesnym prawie węgierskim i roszczeń z nich wypływających, zaznaczając ich odrębności i cechy wspólne z tymi występującymi we współczesnym prawie cywilnym. Przy użyciu komparatystycznej i historycznej metody badawczej umożliwi to ukazanie ponadczasowości określonych problemów prawa zobowiązań, opisując zarazem jego ewolucję w ciągu ostatnich dwóch stuleci.
\end{abstract}

\section{Larva, calumnia, homagium. Torts and non-pecuniary damage in 19th century Hungarian law}

Abstract: The article aims to describe and analyse the ancient Hungarian regulation of tortious liability, considering especially the institute of 'homagium'. Therefore, the author conducts an overview of Hungarian legal history in the 19th century, showing a specific background of its long-lasting continuity and archaism. Furthermore, the classification of torts and remedies present in contemporary Hungarian law is analysed, highlighting their similarities and differences to those used in present civil law. Employing comparative and historical methods enables the author to highlight the timelessness of certain issues of obligation law, showing also its evolution in the last two centuries.

* Opiekun naukowy (Scientific Tutor) — prof. dr hab. Andrzej Dziadzio 


\section{Wstęp}

Doba współczesna jest okresem niezwykle ciekawym i burzliwym dla każdej sfery prawa - dotyczy to również prawa prywatnego. Dynamika zmian społecznych, technologicznych i politycznych połączona z postępującą dekodyfikacją, a zarazem wpływem prawa europejskiego sprzyja pogłębionej refleksji wykraczającej poza li tylko dogmatykę prawną. Nie dziwi zwłaszcza coraz popularniejsze współcześnie sięganie po metody badawcze pozwalające na ukazanie szerszego kontekstu poszczególnych rozwiązań prawnych, w tym komparatystyczną i historyczną. Jest bowiem oczywiste, że prawo nie rozwija się w czasoprzestrzennej próżni.

W niniejszym artykule pragnę skupić się na analizie obszaru szczególnie ciekawego i spornego, jakim jest odpowiedzialność deliktowa — zwłaszcza w sposobie uregulowania jej zakresu czy naprawienia szkody niemajątkowej. Rodząc liczne problemy (skądinąd bliskie również problematyce prawa karnego), jak na przykład sposób ujęcia winy czy umyślności, kwestie te dotykają zarazem spraw żywo dyskutowanych i kontrowersyjnych w prawie polskim ${ }^{1}$. Spojrzenie historyczne, a zarazem komparatystyczne pozwoli zatem nie tylko na poznanie europejskiego (i pośrednio także polskiego) dziedzictwa prawnego, lecz także na refleksję dotyczącą alternatywnych spojrzeń na kwestie aktualne dla współczesnych prawników.

Aktualną problematykę warto bowiem, jak uważam, rozważyć w kontekście zarówno komparatystycznym, jak i historycznym, a zatem w perspektywie porządków prawnych odmiennych zarówno odnośnie do przestrzeni, jak i czasu. Prawo polskie częstokroć bywa porównywane z prawem niemieckim, francuskim bądź anglosaskim, co jest w pełni zrozumiałe w kontekście znaczenia tych porządków prawnych w świecie bądź ich bliskich związków z prawem polskim. Warto jednak sięgać również do systemów mniej znanych i rzadziej analizowanych w Polsce, a do takich zalicza się historyczny system prawa węgierskiego.

Mimo geograficznej i historycznej bliskości wiedza o prawie węgierskim, a tym bardziej o jego historii, jest w Polsce znikoma. Niewątpliwie kluczowym czynnikiem jest tu bariera językowa — całkowita odmienność i stopień skomplikowania języka węgierskiego przekłada się na niewielką liczbę osób nim operujących, co w oczywisty sposób ogranicza możliwość badań nad systemem prawnym i czyni je domeną wąskiej grupy uczonych polskich ${ }^{2}$, mimo że liczne źródła i materiały

${ }^{1}$ Pośród obfitej polskojęzycznej literatury przedmiotu warto zwrócić uwagę w szczególności na: A. Szpunar, Zadośćuczynienie pieniężne za szkodę niemajątkowa, Bydgoszcz 1999; M. Sekuła, Problematyka zadośćuczynienia pieniężnego za szkodę niemajątkowa, , ,Radca Prawny” 2008, nr 2, s. 17 n.; J. Matys, Model zadośćuczynienia pieniężnego z tytułu szkody niemajątkowej w kodeksie cywilnym, Warszawa 2010.

2 Wśród nich należy wymienić przede wszystkim prace prof. Wacława Felczaka, historyka i orędownika przyjaźni polsko-węgierskiej, oraz prof. Józefa Ciągwy, historyka prawa i specjalisty 
dotyczące prawa węgierskiego występują także w języku niemieckim ${ }^{3}$ czy słowackim ${ }^{4}$.

\section{Prywatne prawo węgierskie do XX wieku - ogólna charakterystyka}

Nie tylko wspomniana bliskość przesądza o sensie badań nad dawnym prawem węgierskim. Istotna jest przede wszystkim wyjątkowość tego systemu w skali Europy; aż do XX wieku na Węgrzech została bowiem zachowana ciągłość prawna sięgająca średniowiecza, połączona ze znacznym archaizmem prawa $i$, w zakresie prawa prywatnego, brakiem kodyfikacji aż do roku $1957^{5}$. System ten, pod który podwaliny położył przed tysiącleciem św. Stefan, pierwszy król Węgier, kształtował się przez całe średniowiecze na drodze prawa zwyczajowego i kolejnych cząstkowych aktów prawa partykularnego (ziemskiego, miejskiego, chłopskiego, prowincjonalnego itp.) w sposób zbliżony do prawa staropolskiego. Jego ukoronowaniem było Tripartitum z 1514 roku — spis całości zwyczajowego prawa węgierskiego, który — choć formalnie nie wszedł w życie — był powszechnie stosowany i, na mocy zwyczaju, stał się podstawowym źródłem materialnego prawa cywilnego aż po XX wiek ${ }^{6}$.

Mimo politycznej katastrofy w XVI wieku (upadku średniowiecznego Królestwa Węgier i jego podziału pomiędzy Habsburgów, Turków i książąt Siedmiogrodu) dawne prywatne prawo węgierskie zachowało ciągłość obowiązywania i, ewoluując,

w zakresie historii prawa słowackiego i węgierskiego. Zob. np. W. Felczak, Ugoda węgiersko-chorwacka w 1868 r., Wrocław 1969; J. Ciągwa, Recepcja prawa wegierskiego na Spiszu i Orawie po roku 1920, „Studia Historyczne” 39, 1996, nr 2, s. 199-222; idem, Zniesienie pańszczyzny na Spiszu w latach 1931-1934, „Studia Iuridica Lublinensia” 25, 2016, nr 3, s. 165-178.

${ }^{3}$ Przede wszystkim prace C. Putza: System des ungarischen Privatrechtes, Wien 1870, oraz będąca wstępem do niej Beiträge zur Geschichte des ungarischen Privatrechtes als Einleitung in das Studium desselben, Wien 1869; nadto wcześniejsze pięciotomowe dzieło J. Junga, Darstellung des ungarischen Privat-Rechtes, t. 1-5, Wien 1818 oparte na monumentalnej pracy E. von Kelemena Institutiones Juris privati Hungarici, Pest 1814. Wartościową, dwutomową syntezę prywatnego prawa węgierskiego w jego schyłkowej dobie stworzył A. Almási, Ungarisches Privatrecht, t. 1-2, Berlin-Leipzig 1923-1924; prawo węgierskie badał również E. Heymann (Das ungarische Privatrecht und der Rechtsausgleich mit Ungarn, Tübingen 1917; Das Ungarische Burgerliche Recht und der Rechtsausgleich mit Ungarn, „Juristische Wochenschrift” 46, 1917, s. 352-354).

${ }^{4}$ Ponieważ tereny słowackie aż do 1918 roku nieprzerwanie przez niemal tysiąclecie znajdowały się pod władzą węgierską, opracowania dotyczące historii prawa na Słowacji siłą rzeczy w większej części omawiają prawo węgierskie. Z nowszych syntez warto wskazać przede wszystkim: Š. Luby, Dejiny súkromného práva na Slovensku, Bratislava 2002; oraz J. Beňa, T. Gábriš, Právne dejiny Slovenska I (do roku 1918), Bratislava 2015.

5 W kwestii historycznego rozwoju węgierskiego prawa prywatnego zob. K. Bokwa, Środkowoeuropejskie common law? Prawo zwyczajowe i sędziowskie w Królestwie Węgier w XIX-XX w., „Internetowy Przegląd Prawniczy TBSP UJ” 2018, nr 1 (41), s. 172-181.

6 Š. Luby, op. cit., s. 55 n.

(C) for this edition by CNS 
przetrwało do XIX wieku - niezmienione co do swojej istoty, w dalszym ciągu oparte na feudalnym partykularyzmie, zasadach zebranych w Tripartitum i kolejnych aktach cząstkowych. O ile w zakresie prawa karnego dokonała się w znacznym stopniu recepcja prawa austriackiego (niemieckiego, cesarskiego) ${ }^{7}$, o tyle w zakresie prawa cywilnego wpływy te były pośrednie i znikome. Jak trafnie stwierdził A. Almási, „węgierskie prawo prywatne było do 1848 r. prawem zwyczajowym, opartym na Tripartitum i uzupełnionym nielicznymi ustawami szczególnymi"»

Sytuację zmieniła dopiero Wiosna Ludów i klęska narodowego powstania węgierskiego przeciw Habsburgom, która poskutkowała siłowym narzuceniem prawa austriackiego, w tym kodeksu cywilnego z 1811 roku (ABGB). Jakkolwiek zmiana ta była znaczącym unowocześnieniem systemu prawnego, to, będąc formą politycznych represji, okazała się efemeryczna. Zmiana stosunków politycznych związana z powstaniem dualistycznej Monarchii Austro-Węgierskiej przyniosła swoistą prawną kontrrewolucję; w sposób bezprecedensowy uchylono skodyfikowane prawo stanowione, niemal $\mathrm{w}$ całości powracając do starego systemu prawnego 9 . Przeprowadziła to w 1861 roku tak zwana konferencja judekskurialna ${ }^{10}$ powołana przez cesarza Franciszka Józefa i złożona z czołowych prawników węgierskich. Ów powrót do dawnego prawa miał być tymczasowy, do czasu stworzenia węgierskiej kodyfikacji prawa cywilnego. Ta jednak nie powstała jeszcze przez blisko stulecie.

W efekcie do końca istnienia Królestwa Węgier (formalnie do 1945 roku) prawo prywatne na jego terenie regulowane było przez cząstkowe akty prawne ${ }^{11}$, dawne ustawy i statuty, a nadto zwyczaj i orzecznictwo, zwłaszcza Kurii Królewskiej ${ }^{12}$, której pod koniec XIX wieku formalnie przyznano moc prawną równą ustawie ${ }^{13}$. Prawo węgierskie było zatem swego rodzaju ,żywą skamieliną”, ewenementem w skali europejskiej; zachowując wielowiekową ciągłość prawną, aż do XX wieku przechowało ono średniowieczną systematykę i archaiczną, cząstkową regulację kwestii, które niemal w całej Europie zostały już ujęte w nowoczesnych kodeksach ${ }^{14}$.

7 Zob. A. Dziadzio, Powszechna historia prawa, Warszawa 2009, s. 103.

8 A. Almási, op. cit., t. 1, s. 4; tłum. własne.

9 T. Gábriš, Dočasné súdne pravidlá Judexkuriálnej konferencie z roku 1861, Bratislava 2011, s. $49 \mathrm{n}$.

${ }^{10}$ Węg. Országbirói értekezlet, niem. Judexkurialkonferenz. Wydała ona akt zatytułowany Tymczasowe Zasady Sądowe (węg. Ideiglenes törvénykezési szabályok), który — choć nie był ustawą — stanowił formalną podstawę przywrócenia dawnego systemu prawnego.

11 Dotyczące np. prawa wekslowego czy małżeńskiego; skodyfikowano także prawo handlowe i postępowanie cywilne.

12 Curia Regia, węgierski sąd najwyższy.

13 Zob. K. Bokwa, op. cit., s. 178-180. W kwestii klasyfikacji źródeł dawnego prawa węgierskiego zob. A. Almási, op. cit., t. 1, s. 21-26.

14 J. Beňa, T. Gábriš, op. cit., s. 177-179. 
Niezależnie od tego pod wpływem rzymskim powszechnie przyjmowano na Węgrzech generalny obowiązek naprawienia wyrządzonej bezprawnie szko$\mathrm{dy}^{15}$. Tę zaś dzielono na bezpośrednią (damnum positivum) i pośrednią (damnum negativum $)^{16}$, do tej pierwszej zaliczając damnum emergens, to jest bezpośrednią szkodę rzeczową lub osobową, do drugiej zaś lucrum cessans ${ }^{17}$. Widoczna jest tu zasadnicza zbieżność z współczesną polską klasyfikacją rodzajów szkody majątkowej. Podobnie jak inne archaiczne porządki prawne prawo węgierskie nie wyodrębniało abstrakcyjnej kategorii szkody niemajątkowej.

W związku ze swym archaizmem prawo węgierskie nie znało czytelnej dychotomii na prawo publiczne i prywatne, a przez to również na sankcję publicznoi prywatnoprawną. Widoczne jest to zwłaszcza w typologii czynów zabronionych (deliktów), które w dziewiętnastowiecznej systematyce prawa węgierskiego dzielono na delikty publiczne oraz prywatne. Jedne i drugie były czynami bezprawnymi ${ }^{18}$, za które oprócz obowiązku naprawienia szkody groziła sankcja pieniężna (homagium ${ }^{19}$, fejváltság). Delikty publiczne były ścigane $\mathrm{z}$ urzędu, homagium zaś za ich popełnienie przypadało sędziemu bądź skarbowi królewskiemu ${ }^{20}$; w zasadzie zatem pozostawały domeną prawa karnego i dlatego nie będą one przedmiotem dalszej analizy. Nadto dzielono delikty, według zamiaru, na prawdziwe (vera delicta), to jest popełnione umyślnie (ze złej woli), i quasi delicta (popełnione z niedbalstwa czy lekkomyślności) ${ }^{21}$.

\section{Węgierskie delikty prywatne - ich istota i specyfika}

Szczególną uwagę warto poświęcić sposobowi regulacji deliktów prywatnych, z zasady ściganych na wniosek poszkodowanego i konstrukcyjnie najbliższych współczesnemu rozumieniu szkody spowodowanej czynem niedozwolonym. W doktrynie dzielono je na pięć zasadniczych kategorii ${ }^{22}$ :

— znaczniejsze gwałty (actus maioris potentiae),

— pomniejsze gwałty i akty przemocy (actus minoris potentiae, seu violentiae),

15 J. Jung, op. cit., t. 3, s. 107-108.

16 Aż do lat trzydziestych XIX wieku językiem urzędowym na obszarze Korony Św. Stefana pozostawała łacina, co znajdowało wyraz $\mathrm{w}$ terminologii prawnej.

17 J. Jung, op. cit., t. 3, s. 113.

18 Ibidem, s. 111.

19 Określenie to może być mylące dla badacza polskojęzycznego; w języku polskim, w tym w prawniczym języku kościelnym, „homagium” oznacza „hołd”. Nazwa ta pochodzi od określeń homagium mortuum (lub integrum; węg. holdij) i homagium vivum (lub dimidium, węg. élódij) — tak w średniowieczu określano majątkowe wynagrodzenie, odpowiednio, za zabicie bądź zranienie człowieka. Zob. K. Kadlec, Verböczyovo Tripartitum a soukromé právo uherské i chorvatské šlechty v něm obsažené, Praha 1902, s. 10.

20 C. Putz, System des ungarischen..., s. 299.

21 J. Jung, op. cit., t. 3, s. 108.

22 Za: C. Putz, System..., s. 288. 
— występki popełnione na piśmie (delicta circa literas),

- fałszywe oskarżenia, oszustwa (delicta falsi),

- obrazy honoru.

Oprócz obowiązku naprawy szkody ich popełnienie mogło skutkować infamią bądź utratą honoru, przepadkiem majątku i obowiązkiem zapłaty homagium, które w części lub całości przypadało poszkodowanemu. Nadto sprawcom będącym mieszczanami mógł grozić areszt, chłopom zaś i „ludziom luźnym” — także chłosta $^{23}$. Mimo prywatnoprawnego charakteru czynów i skargowego sposobu dochodzeń roszczeń z nich wypływających delikty prywatne mogły zatem rodzić represje typowo karne. W dawniejszych czasach niektóre spośród nich zagrożone były nawet karą śmierci przez ścięcie, jednak postanowienia te zostały w XVIII i XIX wieku złagodzone bądź uchylone ${ }^{24}$.

Za szczególnie ciekawą formę sankcji grożącej za delikty prywatne trzeba uznać homagium. Wywodziło się ono ze średniowiecznej formy wykupienia się od orzeczonej kary śmierci (stąd inna nazwa - emenda capitis) ${ }^{25}$. Będąc w swojej konstrukcji rodzajem kary kompozycyjnej łączącej cechy współczesnej nawiązki, grzywny i zadośćuczynienia, spełniało ono różnorodne funkcje — represyjne i odszkodowawcze — w odniesieniu zarówno do szkody na osobie bądź rzeczowej, jak i do szkody niemajątkowej. Ta ostatnia cecha warta jest szczególnej uwagi, zważywszy, że dawne prawo węgierskie (podobnie zresztą jak systemy niemiecki czy austriacki ${ }^{26}$ ) nie znało instytucji generalnego pieniężnego zadośćuczynienia za krzywdę.

Co również szczególne, wysokość homagium była uregulowana ryczałtowo i zależała od rodzaju czynu oraz — w niektórych wypadkach — od stanu społecznego poszkodowanego bądź sprawcy; była zatem zobiektywizowana, co istotnie różni ją od zadośćuczynienia za krzywdę bądź nawiązki (art. 445 k.c., art. 46, 47 k.k.) znanych z współczesnego prawa polskiego. Niekiedy homagium podlegało podzieleniu pomiędzy sędziego i poszkodowanego — tak było na przykład w przypadku kwoty 500 forintów przewidywanej za przetrzymywanie cudzych dokumentów, z której 1/3 przypadała sędziemu, 2/3 zaś poszkodowanemu ${ }^{27}$.

Na kwotę należnego homagium znacząco wpływała przynależność stanowa poszkodowanego. W drugiej połowie XIX wieku za popełnienie znaczniejszego gwałtu $^{28}$ na szkodę magnata lub prałata (wyższego duchownego) płacono 400

23 J. Jung, op. cit., t. 3, s. 116.

24 C. Putz, System..., s. 290.

25 Zob. K. Kadlec, op. cit., s. 10.

26 Zob. K. Bokwa, Odszkodowanie oraz zadośćuczynienie w prawie polskim i austriackim. Rys historyczny i prawnoporównawczy, [w:] Pomniki prawa na przestrzeni wieków, red. K. Górski et al., Kraków 2017, s. 134-136.

27 Ustawa XLII z 1659 roku. W tradycji węgierskiej od średniowiecza do XX wieku oznaczano akty prawa stanowionego rokiem wydania i liczbą rzymską.

${ }^{28}$ Zaliczano do tej kategorii między innymi wdarcie się do domu szlachcica lub duchownego, zajęcie gwałtem całego majątku szlacheckiego, zranienie bądź zabicie szlachcica, uszkodzenie kogoś 
forintów ${ }^{29}$, na szkodę szlachcica - 200 forintów, mieszczanina - 100 forintów, a na szkodę chłopa - tylko 40 forintów $^{30}$. Bywało jednak odwrotnie - w przypadku actes minori potentiae wysokość homagium (zwanego w tym wypadku w opracowaniach niemieckojęzycznych Violenzstrafe) zależała od stanu sprawcy. Owa wysokość, jakkolwiek zryczałtowana i przeważnie określona w jednostkowych aktach prawa stanowionego, nie była jednak bezwzględnie wiążąca. $\mathrm{Na}$ modyfikację norm ustawowych wpływało bowiem orzecznictwo, które w prawie węgierskim grało istotną rolę prawotwórczą (zwłaszcza judykatura Kurii). Przykładowo w jednym z jej wyroków z 1869 roku należne szlachcicowi homagium za ciężkie uszkodzenie ciała zostało obniżone ze względu na to, że nie pochodził ze szlachty rodowej, a dopiero sam został nobilitowany ${ }^{31}$.

Obowiązek zapłaty homagium mógł powstać także po stronie miast królewskich, klasztorów i podobnych podmiotów mających osobowość prawną; traktowano je równoznacznie z osobami pochodzenia szlacheckiego. Roszczenie o homagium było natomiast niedziedziczne — śmierć sprawcy lub poszkodowanego przed wystąpieniem przez tego ostatniego z powództwem uniemożliwiała dochodzenie roszczenia.

Poszczególne delikty regulowane były przez jednostkowe, rozproszone akty prawne. I tak na przykład ustawa nr LIX z 1723 roku przewidywała homagium w wysokości 100 forintów za umyślne (świadome) otwarcie korespondencji adresowanej do innej osoby. W normie tej dostrzec można wymiar zarówno represyjny, jak i odszkodowawczy; używając współczesnej terminologii cywilistycznej, była to $\mathrm{w}$ istocie forma zryczałtowanego zadośćuczynienia za naruszenie dobra osobistego w postaci tajemnicy korespondencji, a zarazem sankcja za czyn również obecnie penalizowany (art. 267 k.k.).

Szczególne sankcje groziły nadto za szeroko pojęte oszustwa (delicta falsi), do których zaliczano na przykład podszywanie się pod inną osobę lub cudzy ród (larva, álorczaság) bądź fałszywe negowanie czyjegoś szlachectwa; za tego rodzaju czyny groziło nie tylko homagium, lecz także oddanie w wieczyste (!) poddaństwo poszko-

na ciele w trakcie posiedzenia sądowego bądź sejmikowego czy zranienie krewnego albo osoby mającej list żelazny. Takie wyliczenie wynikało z jednostkowego ustawodawstwa i orzecznictwa częściowo sięgającego XV wieku. Zob. Sz. Bató, Rechtssicherheit im ungarischen Strafrecht vor 1880, [w:] Freiheit - Sicherheit - (Straf)Recht: Beiträge eines Humboldt-Kollegs, red. K. Karsai, F. Nagy, Zs. Szomora, Osnabrück 2011, s. 39 n.

29 Niem. Floren (Fl.) — oficjalna waluta Cesarstwa Austriackiego, potem Austro-Węgier, w latach dziewięćdziesiątych XIX wieku zastąpiona koroną. Znana też pod polskimi nazwami gulden lub złoty reński, a na Węgrzech - forint. Moneta srebrna o masie 12,34 grama (próba srebra 900). W drugiej połowie XIX wieku kwota rzędu 200-400 forintów była znaczną; w ówczesnej Galicji była to cena kilku (od jednej do sześciu, zależnie od okresu, gleby i położenia) mórg gruntu rolnego (morga wiedeńska - 0,5755 ha); pisarz gminny otrzymywał rocznie 15 złotych reńskich. Buty skórzane kosztowały na wsi w Galicji Zachodniej 2-5 złotych, nieco więcej czapka barania. Zob. http://genealog.mrog.org/wartosc_pieniadza.html (dostęp: 13.02.2020).

30 C. Putz, System..., s. 290-291.

31 Sz. Bató, op. cit., s. 39. 
dowanemu (jobbagionalis subjectio) ${ }^{32}$. Podobna kara groziła również za „zdradę krwi" (proditio fraterni sanguinis, vértagadás), czyli działanie na szkodę najbliższych krewnych. Feudalność prawa była w tym wypadku widoczna nie tylko w zróżnicowaniu sankcji, ale też w różnej właściwości sądu, zależnej od stanu sprawcy.

Homagium mogło nadto być instrumentem sankcji za bezzasadne wytaczanie oskarżeń. W wypadku niektórych skarg (między innymi o actes minori potentiae) w razie wykazania w toku przewodu sądowego bezzasadności oskarżenia powód był zobowiązany do wypłacenia pozwanemu kwoty równej homagium, o jakie występował, co oparto na zasadzie talionu (poena talionis) ${ }^{33}$. Była to więc sankcja znacznie surowsza niż przewidywany przez współczesne ustawy procesowe, a będący jej odpowiednikiem obowiązek zwrotu kosztów postępowania czy reprezentacji strony przeciwnej.

Bezzasadna litygacja mogła być także uznana za osobny delikt kalumnii (calumnia), mianowicie jeśli wytaczano proces wbrew prawu lub bez podstawy prawnej bądź złośliwie. Do sytuacji takich zaliczano na przykład równoczesne żądanie tej samej rzeczy na podstawie różnych tytułów prawnych (sub duplici colore) bądź przed dwoma różnymi sądami; kalumnią było także występowanie przed sąd z żądaniem już zaspokojonym bądź ugodowo załatwionym. W takich wypadkach homagium wynosiło 200 forintów, z których 2/3 otrzymywał sędzia, $1 / 3$ zaś bezzasadnie pozwany.

W przedstawionych sytuacjach obowiązek zapłaty homagium był zatem formą sankcji za „nadużywanie prawa procesowego” bądź nielojalność wobec stron i sądu przez świadome naruszanie zasad litis pendentio i res iudicata, obecnych w prawie węgierskim pod wpływem rzymskim. Zarazem chodziło o zadośćuczynienie osobie niesłusznie pozwanej, na którą tego rodzaju oskarżenia (czyli właśnie kalumnie) mogły rzucać niekorzystne światło i uchybiać jej honorowi. W tym więc wypadku homagium (a przynajmniej jego część przyznawana poszkodowanemu) stanowiło formę zadośćuczynienia za umyślne naruszenie dóbr osobistych oraz konieczność uczestnictwa w bezpodstawnym procesie. Część zaś wypłacaną sądowi można uznać za sankcję wykazującą podobieństwa zarówno do obowiązku pokrycia kosztów sądowych, jak i do grzywny w rozumieniu prawnokarnym.

\section{Podsumowanie}

Regulacja prawa węgierskiego zasadniczo odróżniała się swoją anachronicznością od obecnych w pozostałych systemach dziewiętnastowiecznej Europy, tym bardziej zaś od współczesnych regulacji odpowiedzialności deliktowej. Owa „żywa skamielina” prawna, tkwiąc korzeniami w prawie średniowiecznym, nie tworzyła klarownej dychotomii na sankcję publiczną i prywatną. Przedstawione

\footnotetext{
32 Ustawa XLVI z 1723 roku, zob. J. Jung, op. cit., t. 3, s. 165; K. Kadlec, op. cit., s. 281.

33 Paragraf 3 ustawy XXIII z 1613 roku.
} 
rozważania pokazują jasno, że nie sposób zrównywać węgierskich deliktów prywatnych z deliktami - czynami zabronionymi - w rozumieniu współczesnego polskiego prawa cywilnego (art. 415 i nast. k.c.), mając na uwadze zwłaszcza rodzaje sankcji grożących za te pierwsze. Pośród nich wyróżnia się homagium będące swoistą, zryczałtowaną formą zarówno majątkowej represji karnej, jak i zadośćuczynienia za szkodę niemajątkową.

Doktryna węgierska po konferencji judekskurialnej zauważała anachroniczność instytucji homagium i postulowała jej likwidację, co znalazło wyraz w ustawie LII z 1871 roku znoszącej również kary cielesne za delikty prywatne ${ }^{34}$. Był to niewątpliwie krok ku unowocześnieniu węgierskiego systemu prawa cywilnego i oddzieleniu go od prawa karnego. Zarazem był to element niwelowania różnic stanowych esencjonalnych dla regulacji homagium, które w Europie drugiej połowy XIX wieku było już rażąco anachroniczne. Niezależnie jednak od przestarzałości homagium jako instytucji stanowiło ono oryginalny sposób na uzyskiwanie materialnej rekompensaty przez osoby pokrzywdzone napaściami fizycznymi, pomówieniami, obrazami honoru czy nękaniem bezpodstawnymi procesami - i to w sytuacji niewystępowania w systemie prawnym generalnej zasady obowiązku naprawienia szkody niemajątkowej oraz ochrony dóbr osobistych, których koncepcja dopiero się wówczas rodziła.

Ten fakt czyni homagium ciekawym przedmiotem refleksji, zwłaszcza w dobie niesłabnących kontrowersji zarówno co do zakresu ochrony dóbr niemajątkowych, jak i jej sposobu. Zarazem instytucja ta jest jedynie drobnym wycinkiem całego systemu prywatnego prawa węgierskiego, który wciąż czeka na odkrycie przez polskich badaczy. Niewątpliwie kryje on wiele materii do dyskusji nie tylko dla historyków, lecz także dla współczesnych prawników; jego wyjątkowa archaiczność, a jednocześnie zdolność do funkcjonowania w relatywnie nowoczesnym społeczeństwie może okazać się nie tylko historyczną ciekawostką, lecz również inspiracją dla rozwiązań problemów, przed którymi staje współczesne prawo zobowiązań.

\section{Bibliografia}

Almási A., Ungarisches Privatrecht, t. 1-2, Berlin-Leipzig 1923-1924.

Bató Sz., Rechtssicherheit im ungarischen Strafrecht vor 1880, [w:] Freiheit - Sicherheit - (Straf)

Recht: Beiträge eines Humboldt-Kollegs, red. K. Karsai, F. Nagy, Zs. Szomora, Osnabrück 2011, s. $25-45$.

Beňa J., Gábriš T., Právne dejiny Slovenska I (do roku 1918), Bratislava 2015.

Bokwa K., Odszkodowanie oraz zadośćuczynienie w prawie polskim i austriackim. Rys historyczny i prawnoporównawczy, [w:] Pomniki prawa na przestrzeni wieków, red. K. Górski, J. Pokoj, D. Szczepaniak, Ł. Szymura, Kraków 2017, s. 131-140.

34 Sz. Bató, op. cit., s. 39. 
Bokwa K., Środkowoeuropejskie common law? Prawo zwyczajowe i sędziowskie w Królestwie Węgier w XIX-XX w., „Internetowy Przegląd Prawniczy TBSP UJ” 2018, nr 1 (41), s. 172-181.

Ciągwa J., Recepcja prawa węgierskiego na Spiszu i Orawie po roku 1920, „Studia Historyczne” 39, 1996, nr 2, s. 199-222.

Ciągwa J., Zniesienie pańszczyzny na Spiszu w latach 1931-1934, „Studia Iuridica Lublinensia” 25, 2016, nr 3, s. 165-178.

Dziadzio A., Powszechna historia prawa, Warszawa 2009.

Felczak W., Ugoda węgiersko-chorwacka w 1868 r., Wrocław 1969.

Gábriš T., Dočasné súdne pravidlá Judexkuriálnej konferencie z roku 1861, Bratislava 2011.

Heymann E., Das Ungarische Burgerliche Recht und der Rechtsausgleich mit Ungarn, „Juristische Wochenschrift" 46, 1917.

Heymann E., Das ungarische Privatrecht und der Rechtsausgleich mit Ungarn, Tübingen 1917.

Jung J., Darstellung des ungarischen Privat-Rechtes, t. 1-5, Wien 1818.

Kadlec K., Verböczyovo Tripartitum a soukromé právo uherské i chorvatské šlechty v něm obsažené, Praha 1902.

Kelemen E. von, Institutiones Juris privati Hungarici, Pest 1814.

Luby Š., Dejiny súkromného práva na Slovensku, Bratislava 2002.

Matys J., Model zadośćuczynienia pieniężnego z tytułu szkody niemajątkowej w kodeksie cywilnym, Warszawa 2010.

Putz C., Beiträge zur Geschichte des ungarischen Privatrechtes als Einleitung in das Studium desselben, Wien 1869.

Putz C., System des ungarischen Privatrechtes, Wien 1870.

Sekuła M., Problematyka zadośćuczynienia pieniężnego za szkodę niemajątkowa, „Radca Prawny” 2008, nr 2.

Szpunar A., Zadośćuczynienie pieniężne za szkodę niemajątkowa, Bydgoszcz 1999. 